\title{
Obituary for Olaf Breidbach
}

\author{
Jürgen Jost
}

Published online: 4 November 2014

(C) Springer-Verlag Berlin Heidelberg 2014

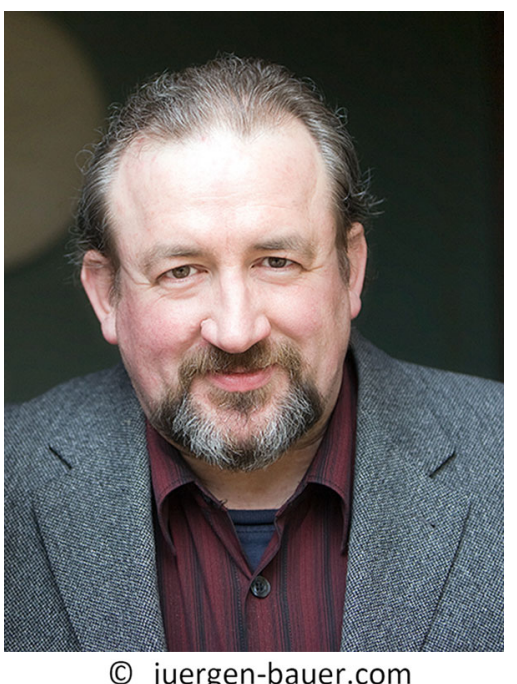

(c) juergen-bauer.com

It is my sad duty to inform the readers of Theory in Biosciences that our Editor-in-Chief Olaf Breidbach passed away on July 22 at the age of 56 after a long and painful illness.

Few of our readers may know the enormous span and the multitude of facets of his scientific work, and even those may not have experienced his personality which at the same time was very original and deeply human. Therefore, let me start this obituary by recalling how he transformed the journal into what it stands for now, a site for the open discussion of all theoretical aspects of biology, its concepts and history, as well as substantial

J. Jost $(\bowtie)$

MPI Mathematics in the Sciences, Inselstraße 22,

04103 Leipzig, Germany

e-mail: jjost@mis.mpg.de mathematical or other theoretical contributions to contemporary biology. Before Olaf Breidbach took over the journal, it had a different concept, a different name, and was written in a different language. It had been founded in 1881 by the German physiologist Julius Isidor Rosenthal (1836-1915) as "Biologisches Centralblatt", with the intention of reporting in a regular manner about the progress of the biological sciences. For a long time, it had enjoyed quite some status for biological research in Germany, but eventually it had outlived its time. When Olaf Breidbach came to Jena in 1995-more on this below-he soon got into contact with the local publishing house Gustav Fischer in whose hands the journal had found itself after the collapse of the GDR. It was then decided to relaunch the journal with a radically new format, to transfer the original intention of a critical review of biological research into an international frame. In the beginning, he edited the journal together with the philosopher Michael Weingarten, but to broaden its scope, he co-opted first myself, a mathematician, and then Peter Stadler, a theoretical chemist and bioinformatician, as editors because we shared an active interest in theoretical and mathematical biology. He also recruited a board of associate editors of high international reputation and wide-ranging scientific expertise. This was also the period of profound economic changes in the publishing sector. Gustav Fischer merged into the publishing house Urban and Fischer which in turn was soon bought up by Elsevier. After some time, Elsevier suddenly decided to discontinue the journal because it did not generate enough profit for them. Fortunately, we could then move to Springer as the new publisher of Theory in Biosciences.

So, who was the man who created Theory in Biosciences as you know it? Let me begin with a biographical sketch. He was born in 1957 and grew up in the low mountain 
region Bergisches Land in the Rhineland in west of Germany. He then studied art science, philosophy, biology, and paleontology at the University of Bonn. He obtained two $\mathrm{PhD}$ degrees, one in 1982 in philosophy on the concept of the organic in the work of the German idealist philosopher Hegel (1770-1831), and another one in 1984 in biology on the longhorn beetle (hylotrupesbajulus) of the Cerambycidae family. From 1985 to 1987, he worked with a Liebig fellowship at the University of Cologne on the metamorphosis of the beetle brain. He then returned to Bonn to build up a group on neuronal development, and in 1989, he obtained his habilitation in zoology. During this period, he produced substantial work on the nervous system of invertebrates, combining an evolutionary and a comparative approach. In 1994, to also investigate the more abstract and theoretical aspects of neuronal networks and the dynamics and evolution of structures, he joined me in the mathematics department of the Ruhr University Bochum. He also worked on the conceptual history of the neurosciences, leading to his widely acclaimed monograph "Die Materialisierung des Ichs" (The Materialization of the Self), which appeared in 1997. In 1995, he was awarded the Chair for the History of Science at the University of Jena, combined with the directorships of the Institute for the History of Medicine, Science, and Technics and of the museum "Ernst-Haeckel-Haus" at that university.

Ernst Haeckel (1834-1919), after whom the institute and the museum had been named, was the biologist and naturalist who had been the first and most vociferous proponent of Darwin's theory of evolution in Germany. His popular account of Darwin's theory "Natürliche Schöpfungsgeschichte" (The History of Creation) had a substantial international impact. Haeckel is known among biologists for his "biogenetic law" that "ontogeny recapitulates phylogeny", which postulates that the embryonic development of organisms repeats forms of ancestral species. The strong form that Haeckel gave to his law, however, was not supported by subsequent biological research. In any case, Haeckel was a very skillful and meticulous biological observer, and he named several thousand new biological species and proposed the animal kingdom Protista. Ernst Haeckel also possessed artistic skill, and his colorful illustrations of animals and sea creatures, "Kunstformen der Natur" (Art Forms of Nature) range from the rigid geometrical structures of the mineral skeletons of Radiolariae to the undulating, flowering forms of Medusae. The latter even exerted an influence on the development of the Art Nouveau and Jugendstil around the turn of the century. Haeckel was also a self-acclaimed philosopher and wrote books for the general public, in particular the very popular "Die Welträtsel" (The Riddles of the Universe). In 1905 , he founded a group called the "Monist League" to promote his religious and political beliefs, and he organized an international ceremony to have himself elected as the antipope. In hindsight, his philosophical, social, and political beliefs appear as a rather crude mixture of romanticism, atheism, and a popularized version of Darwinism, and they may have had a pernicious influence on some parts of the German public.

Thus, Haeckel was a colorful and controversial figure, and Olaf Breidbach, as director of the Ernst Haeckel house, was in charge of his legacy. While as a Catholic Christ and a deeply human thinker, he was critical of many of the views of Haeckel and found some of them repulsive, he nevertheless fulfilled his role with admirable intellectual dignity. While being open about his criticism of Haeckel's ideology, he edited his scientific and artistic works with dedication, skill, and strict scientific standards. In particular, he brought out several editions of Haeckel's "Kunstformen der Natur", thereby making them widely available again. He had also started the edition of the huge collection of Haeckel's letters, an editorial project conceived for several years, but his illness did not allow him to complete it.

In fact, Olaf Breidbach was one of the most productive and prolific editors that the history of biology has ever seen. Among others, he edited works of: Caspar Wolff (1735-1794) who had proposed his theory of epigenesis against the concept of preformation that the embryo already possessed all the features of the adult organism in some miniature form, which was the prevailing view at his time; the botanist and co-founder of the cell theory, Matthias Schleiden (1804-1881); the founder of embryology and the discoverer of the mammalian egg cell, Karl Ernst von Baer (1792-1876); Sigmund Exner (1846-1926) who worked on comparative physiology and the psychology of perception; the natural philosopher, Lorenz Oken (1779-1851), who had coined much of the biological terminology that is still in use today; the idealist philosopher, Karl Christian Friedrich Krause (1781-1832), whose system had exerted a profound influence on modern philosophy in Spain and Latin America; the biologist Fritz Müller (1821-1897), who had emigrated to Brazil and performed important work on its natural history; the artist, naturalist, and scientist Carl Gustav Carus (1789-1869), who had introduced the concept of the vertebrate archetype; the Russian and Soviet zoologist Ivan I. Schmalhausen (1884-1963), who had contributed to the modern evolutionary synthesis; and the brothers Armin (1870-1952) and Erich (1871-1962) von Tschermak-Seysenegg who, as Olaf Breidbach and his coworkers discovered, had not been rediscoverers of Mendel's law, but in fact had been aware of them all along. He also edited the "Historia Animalium" of the Swiss naturalist Conrad Gesner (1516-1565), a huge encyclopedia of animals that is considered to be the first modern zoological work. Also, for many years, Olaf 
Breidbach had been fascinated by the Jesuit scholar and polymath Athanasius Kircher (1602-1680), whose work spanned such diverse topics as oriental studies, geology, and medicine, but whose underlying basic project was a general system of all knowledge, and he had therefore also planned an edition of Kircher's works. In some sense, Olaf Breidbach viewed Kircher's wide-ranging scheme as an alternative to the rationalist strategy that came to dominate the subsequent development of science, and in Kircher's combinatorial tables he saw some kind of forerunners of the association schemes that constitute the basis of modern neural networks.

For a wider scope, together with myself, he also founded a new series in the history of science whose purpose is to make classic scientific texts available to modern readers with an extensive historical and systematic commentary. He saw this series as a modern version of the famous "Ostwalds Klassiker der exakten Wissenschaften" that had been founded by the physical chemist Wilhelm Ostwald in 1889 to make the most important scientific treatises available to the general public. The volumes in our series thus range from biology and medicine to mathematics, physics, and engineering. In any case, he saw his editorial work not simply as a philological task, but as a means to elucidate important scientific concepts in their historical contexts. His introductions and commentaries to the various texts he had edited identify, discuss, and sometimes also criticize the key concepts, views, and ideas of their authors with admirable clarity, depth, and perspicacity and carefully analyze their place and their role in the historical lines of development.

He not only performed editorial, but also systematic work in the history of science. In particular, he was keenly aware of the critical role of technology for providing precision measurement tools and recording and visualization devices for the development of science. Together with his students, he systematically reconstructed and tested old measurement techniques, to see what could and what could not be achieved with them, and in particular what precision and accuracy could be achieved with the level of craftsmanship available at their time. Also, when the lethal illness was diagnosed, he was occupied with a comprehensive history of science from antiquity to modern times that was planned to consist of six volumes; but alas, only the first volume could be completed.

He was, however, not just interested in the history of science, but in the much wider context of the history of ideas. A particular focus of his interest was the period around 1800 which saw a proliferation of literary, philosophical, and scientific ideas in the middle German region of Weimar and Jena, the Weimarer Klassik with the writers and theoreticians Goethe, Schiller, Herder, Wieland in Weimar, the romantic movement of the Schlegel brothers,
Novalis and others, as well as the idealist philosophers Fichte, Schelling, and Hegel or scientists like the physicist Ritter, who did important research on phenomena of electricity, and the chemist Döbereiner, a forerunner of the periodic table of elements, in Jena. Olaf Breidbach initiated and directed, together with his colleague Klaus Manger, a large-scale research project, a so-called Sonderforschungsbereich, of the German National Research Society DFG devoted to this topic. He also produced two highly regarded monographs about the scientific work of Johann Wolfgang von Goethe (1749-1832), Germany's foremost literary figure, analyzing his conception of the metamorphosis of plants as well as his theory of color. In fact, as Olaf Breidbach worked out in detail, Goethe's ideas about an archetypical form from which the leaves and petals of all modern plants are derived by continuous transformations, as well as his discovery of the human intermaxillary bone based on careful anatomical work on various mammal species, were constitutive for the development of the science of morphology.

Although the volume, substance, originality, and depth of the aforementioned work are rivalled by very few, if any, historians of science, this was far from being the only field in which Olaf Breidbach has made profound contributions. He was also an accomplished experimental and theoretical neurobiologist, an evolutionary biologist, a philosopher, a system theorist, and a theoretician of art. Most importantly, he could link all these diverse domains of his scientific interest, because he saw a fundamental unity, or perhaps better, a tightly woven web connecting all these areas. Let me try to follow some of these intellectual threads without getting too entangled in the intricacies of this web. His experimental work on insect neuroanatomy and morphology on one hand led him to understand how a basic design of a neurocontroller can be coupled with a variety of different actuators to produce a wide range of behavior in insects, that is, to a fundamental neurobiological principle. At a more abstract level, for understanding the basic principle of brains and their interaction with environments as mediated by sensors and actuators, instead of the fashionable sensorimotor loops, he focused on the intrinsic neuronal dynamics. According to the view he developed, and about which we had many discussions over several decades, sensory input modulates this internal dynamics, and in mathematical terms, we were thinking about attractor dynamics and transients and their perturbations in dynamical systems. On this basis, he also conceived principles of neurophilosophy, and his ideas about neuronal esthetics, for instance, then tried to understand how ideas of beauty are related to such neuronal dynamics. He was intellectually always very careful not to postulate any crude correspondence between thinking and feeling on one side and brain dynamics on the other, but he searched 
for a deeper relation. In this regard, also his understanding of the history and the practice of art helped him to appreciate the depth of the problem. In fact, he not only was a profound theoretician of art, but also an accomplished artist himself. A painting of his inspired by the morphology of insects has been decorating my living rooms in the various apartments and houses I have been living in during the last 30 years.

His work in the history of science, his ideas about neuronal esthetics, and the visual insights that he possessed as an artist contributed to his profound understanding of the role of pictures and other visualization techniques for the process of generation and codification of scientific knowledge. But he was also interested in wider aspects of the concept of knowledge and its role in our society. Knowledge for him was more than the sum of available pieces of information. Its basic aspect is relational, providing a scaffold for integrating new information and thereby assigning meaning to it. This led him to a profound analysis of our modern information society that combined the achievements of a long philosophical tradition with modern neurobiological findings and insights, like those indicated above. In a different direction, but on the same basis, together with his friend Federico Vercellone, he also worked on the philosophical and artistic concept of "Anschauung" that links perception, intuition, and contemplation. Combining the above approach to knowledge with his analysis of evolution, to be addressed in more detail below, and his profound understanding of the socalled "hermeneutic circle" which implies that our thinking can take place only within the patterns provided by our culture, he also provided a new perspective on the status of scientific knowledge in his recent monograph "Radikale Historisierung". In this book, he suggested a way to cope with the relativity of our knowledge through a deeper understanding of that relativity itself.

Returning to his work on insect brains, this also led him to insights into the creation, modification, and preservation of structures by the forces of evolution. On one hand, it was clear to him that there were more general units and more abstract features of biological evolution than simple (caricatures of) genes. He tried to identify the concepts and to understand the mechanisms. Concerning the concepts, we worked on the formalization of the concept of a species, trying to go beyond the version of Ernst Mayr and to characterize a species as a dynamical balance between diverging forces such as differential selection in a heterogeneous and varied habitat, the random components of genetic drift and mutations, and the converging effects of sexual recombination. On the basis of such dynamical theories, we also discussed the interactions of species in ecosystems and, on this basis, a new conceptual foundation for ecology. Species, however, also have an important historical dimension, and the conceptual question of ancestry then turns into the paleontological task of identifying relations between fossils. Here, in the tradition of Goethe and others, he searched for general principles of morphology, that is, of functional patterns and structures. He also initiated a discussion in Theory of Biosciences on the concept of the gene, the second fundamental concept of evolutionary biology.

Of course, but unfortunately, there are many unscientific attacks on the concept of biological evolution by so-called creationists and other misguided religious zealots, but Olaf Breidbach, being a devoted Catholic himself, was adamant in his rejection of any such approaches. He saw no contradiction between his religious beliefs and his science in evolution or neurobiology. His religion, however, led him to clear and straight ethical principles, and he was therefore opposed to biological research that involved tinkering with what might potentially be human life. The dignity of human life was not an abstract principle for him, but covered concrete entities like embryonic stem cells.

During the last decade, his family life had been no longer so happy. He was concerned with the development and the future of his two sons to whom he was deeply attached. Nevertheless, his scientific productivity continued undiminished even through difficult private times. In fact, he was reaching ever higher levels of scientific insight and comprehension, and it could have been expected that his scientific work could achieve an even higher quality and unity weaving together the different threads of his scientific endeavors in an integrated whole. Alas, this was cut short by a deadly illness.

Olaf Breidbach has been one of the foremost German scientists and intellectuals of our time. The originality, the depth, the penetrating, and critical power of his thinking, and the wide range of fields that he covered and mastered remain unequalled. For me, he had been the most important intellectual partner and best friend for almost four decades since we first met in Bonn as young students.

Hardly ever had there been a more bitter loss.

Jürgen Jost 